\title{
FASILITAS PPN TIDAK DIPUNGUT ATAU DIBEBASKAN: PERBEDAAN DAN PERMASALAHAN
}

\author{
Suparna Wijaya ${ }^{1}$, Komang Rina Arsini ${ }^{2}$ \\ Politeknik Keuangan Negara STAN ${ }^{1}$, Direktorat Jenderal Pajak ${ }^{2}$ \\ sprnwijaya@pknstan.ac.id ${ }^{1}$, rinaarsini58@gmail.com ${ }^{2}$
}

\begin{abstract}
ABSTRAK
Tujuan penelitian ini adalah mengetahui perbandingan antara fasilitas PPN tidak dipungut dan fasilitas dibebaskan dari pengenaan PPN serta mengetahui permasalahan yang ditimbulkan oleh penerapan tersebut. Metode dalam penelitian ini adalah kualitatif deskriptif dengan dokumentasi dan wawancara kepada beberapa narasumber. Terdapat perbedaan yang signifikan antara ketentuan pengkreditan Pajak Masukan (PM) yang dibayar untuk perolehan Barang Kena Pajak (BKP) dan/atau perolehan Jasa Kena Pajak (JKP) terkait penyerahan yang mendapat fasilitas PPN (Pajak Pertambahan Nilai) tidak dipungut dengan penyerahan yang mendapat fasilitas dibebakan dari pengenaan PPN. PM yang tidak dapat dikreditkan terkait penyerahan yang mendapat fasilitas dibebaskan dari pengenaan PPN dikhawatirkan dapat mempengaruhi harga jual dari BKP yang mendapat fasilitas tersebut. Hasil penelitian menunjukan bahwa perbedaan fasilitas PPN tidak dipungut dan dibebaskan dari pengenaan PPN dapat dilihat dari tiga aspek, yaitu dari segi pengkreditan PM, administrasi, dan sudut pandang ekonomi. PM yang tidak dapat dikreditkan dan dibiayakan oleh pengusaha memiliki kemungkinan mempengaruhi harga barang menjadi lebih tinggi apabila berada pada pasar yang bersifat monopolistik (monopoli atau oligopoli). Sebaliknya, PM yang tidak dapat dikreditkan dan dibebankan sebagai biaya oleh PKP tidak akan mempengaruhi harga barang apabila jenis pasar barang tersebut adalah pasar persaingan sempurna.
\end{abstract}

Kata Kunci: Pajak Pertambahan Nilai, Fasilitas PPN, Pajak Masukan

\begin{abstract}
There is a significant difference between the provisions for crediting the Input Tax (PM) that is paid for the acquisition of Taxable Goods (BKP) and / or for the acquisition of Taxable Services $(J K P)$ related to the delivery that is free of VAT facilities and the delivery which is free from the imposition of VAT. It is feared that the PM who cannot be credited regarding the delivery of the facility that is exempted from VAT is feared to affect the selling price of the BKP receiving the facility. The purpose of this research is to find out the comparison between free VAT facilities and facilities exempt from VAT imposition and to know the problems caused by the implementation of the VAT facilities. The method used in this research is descriptive qualitative with documentation and interviews with several sources. The results showed that the difference between free and exempt VAT facilities from the imposition of VAT can be seen from three aspects, namely in terms of PM crediting, administration, and an economic point of view. PM that cannot be credited and financed by entrepreneurs has the possibility to increase the price of goods if they are in a monopolistic market (monopoly or oligopoly). Conversely, PM that cannot be credited and charged as a fee by the PKP will not affect the price of the goods if the type of market for the goods is a perfectly competitive market.

Keywords: Value Added Tax, VAT facilities, VAT Input
\end{abstract}




\section{PENDAHULUAN}

Salah satu wujud kemandirian bangsa dalam pembiayaan pembangunan nasional adalah pajak. Pajak merupakan sumber penerimaaan negara terbesar dan memiliki kecenderungan semakin meningkat setiap tahunnya. Selain itu, pembayaran pajak merupakan perwujudan dari kewajiban kenegaraan dan peran serta Wajib Pajak untuk pembiayaan negara dan pembangunan nasional (Afriyanti, 2014).

Namun, hingga saat ini tax ratio Indonesia masih tergolong rendah. Organisation for Economic Co-operation and Development (OECD) merilis Revenue Statistic in Asia and Pasific Economies 2019 yang menempatkan tax ratio Indonesia di posisi paling bawah (Suwiknyo, 2019). Berdasarkan data Kementerian Keuangan, tax ratio Indonesia pada tahun2014 sebesar 13,7\%, 2015 sebesar 11,6\%, 2016 sebesar 10,8\%, 2017 sebesar 10,7\%, 2018 sebesar 11,6\% dan tax ratio 2019 sebesar 12,2\%. OECD menyebut rasio pajak Indonesia tersebut masih berada di bawah rata-rata OECD sebesar 34,2\% bahkan juga di bawah Afrika yang rata-rata tax ratio-nyasebesar 18,2\%.

Sedangkan realisasi penerimaan pajak tahun 2019 mencapai Rp1.332,06 triliun. Pajak Pertambahan Nilai (PPN) dan Pajak Penjualan atas Barang Mewah (PPnBM) memberikan kontribusi yang cukup besar bagi total penerimaan pajak yaitu sebesar 532,91 triliun rupiah atau sebesar 40,007\% dari total penerimaan pajak. Oleh sebab itu, sangat wajar apabila pemerintah terus berupaya meningkatkan penerimaan negara utamanya penerimaan pajak. Salah satu jalan yang ditempuh adalah pemberian fasilitas atau kemudahan dalam bidang Pajak Pertambahan Nilai.

Estimasi belanja perpajakan atau tax expenditure yang berasal dari pemberian kemudahan atau fasilitas di bidang PPN dan PPnBM cenderung meningkat setiap tahunnya yaitu pada tahun 2016 sebesar 116.326 miliar rupiah, pada tahun 2017 sebesar 132.848 miliar rupiah, dan pada tahun 2018 sebesar 145.615 miliar rupiah. Belanja perpajakan dari fasilitas PPN dan PPnBM adalah belanja perpajakan yang terbesar dimana belanja perpajakan ini mencapai 60 persen dari total estimasi belanja perpajakan yaitu sebesar 192.563 miliar rupiah pada tahun 2016, sebesar 196.821 miliar rupiah pada tahun 2017, dan sebesar 221.121 miliar rupiah pada tahun 2018 (Badan Kebijakan Fiskal, 2019). Dengan besarnya belanja perpajakan yang dilakukan untuk memberikan fasilitas di bidang PPN, tentunya diharapkan dapat mendorong perekonomian agar tumbuh cukup tinggi dan berkelanjutan sehingga target penerimaan pajak dapat tercapai.

Kemudahan atau fasilitas di bidang Pajak Pertambahan Nilai (PPN) diatur dalam pasal 16B UU PPN yang terdiri dari Pajak Pertambahan Nilai terutang tidak dipungut sebagian atau seluruhnya dan dibebaskan dari pengenaan Pajak Pertambahan Nilai. Terdapat perbedaan yang signifikan antara fasilitas PPN tidak dipungut dan PPN dibebaskan. Pajak Masukan yang dibayar untuk perolehan Barang Kena Pajak (BKP) 
dan/atau perolehan Jasa Kena Pajak (JKP) yang atas penyerahannya tidak dipungut PPN dapat dikreditkan. Sedangkan Pajak Masukan yang dibayar untuk perolehan BKP dan/atau JKP yang atas penyerahaan dibebaskan dari pengenaan PPN tidak dapat dikreditkan.

Fasilitas dibebaskan dari pengenaan PPN tidak akan menimbulkan permasalahan apabila diterapkan di kawasan tertentu atau tempat tertentu di dalam Daerah Pabean karena pada saat pemasukan barang ke kawasan atau tempat tertentu pada umumnya mendapat fasilitas PPN tidak dipungut. Sehingga ketika penyerahan atau pengeluaran BKP dari kawasan atau tempat tertentu di dalam Daerah Pabean ke Tempat Lain dalam Daerah Pabean diberikan fasilitas dibebaskan dari pengenaan PPN, hal tersebut tidak akan mempengaruhi harga pokok penjualan dari BKP tersebut.

Masalah baru akan timbul ketika fasilitas pembebasan dari pengenaan PPN diberikan bagi penyerahan BKP di Tempat Lain dalam Daerah Pabean. Fasilitas pembebasan dari pengenaan PPN akan memberikan masalah bagi Pengusaha Kena Pajak di Tempat Lain dalam Daerah Pabean karena Pajak Masukan yang berkaitan dengan penyerahan BKP tidak dapat dikreditkan sehingga Pajak Masukan tersebut menjadi komponen dari harga pokok penjualan BKP. Dengan asumsi margin keuntungan yang diperoleh perusahaan tidak berubah, harga jual BKP tersebut akan meningkat karena harga pokok penjualan meningkat. Sehingga masyarakat luas akan merasa kesulitan untuk menanggung harga jual BKP yang mendapat fasilitas dibebaskan dari pengenaan PPN.

Para pelaku usaha merasa terbebani atas fasilitas dibebaskan dari pengenaan PPN. Salah satunya adalah Ketua Umum Ikatan Penerbit Indonesia (IKAPI) Rosidayati Rozalina mengatakan, pihaknya terus memperjuangkan penghapusan pajak buku. Pajak buku membuat pajak berlipat yang harus ditanggung penerbit dan penulis mulai dari bahan baku kertas, biaya pencetakan buku, serta royalti penulis dan badan hukum (Sulistyawati, 2019). Contoh lain adalah Direktur PT. Ciputra Development Tbk, Harun Hajadi menilai bahwa selain memberikan fasilitas pembebasan PPN bagi rumah sederhana dan rumah sangat sederhana, sebaiknya diberikan juga intensif perpajakan kepada kontraktor. Karena jika tidak, Pajak Masukan yang telah dibayarkan oleh kontraktor tidak dapat dikreditkan sehingga akan menambah biaya atas pembangunan rumah sederhana dan rumah sangat sederhana tersebut (ortax.org).

Pajak adalah iuran rakyat kepada kas negara berdasarkan undang-undang (yang dapat dipaksakan) dengan tidak mendapat jasa timbal (kontraprestasi) yang langsung dapat ditunjukkan dan yang digunakan untuk membayar pengeluaran umum (Mardiasmo, 2011). Sedangkan menurut Sommerfeld Ray M., Anderson Herschel M, dan Brock Horace, dalam Sumarsan (2017), pajak merupakan suatu pengalihan sumber dari sektor swasta ke sektor pemerintah, yang bukan akibat pelanggaran hukum namun 
wajib dilaksanakan, berdasarkan ketentuan yang telah ditetapkan lebih dulu, tanpa mendapat imbalan yang langsung dan proporsional, agar pemerintah dapat melaksanakan tugas-tugasnya untuk menjalankan pemerintahan.

Menurut (Pietersz et al., 2021) Pajak berfungsi sebagai sumber dana yang diperuntukkan bagi pembiayaan pengeluaran-pengeluaran pemerintah dalam APBN (Anggaran Pendaptan Belanja Negara), pajak merupakan sumber penerimaan dalam negeri. Pajak berfungsi sebagai alat untuk mengatur atau melaksanakan kebijakan di bidang sosial dan ekonomi.

Menurut Diana Sari dalam Hestanto (2018), "terdapat dua fungsi pajak, antara lain: a. Fungsi Penerimaan (Budgetair), yaitu sebagai alat (sumber) untuk memasukkan uang sebanyak-banyaknya dalam Kas Negara dengan tujuan untuk membiayai pengeluaran negara yaitu pengeluaran rutin dan pembangunan. Sebagai sumber pendapatan negara pajak berfungsi untuk membiayai pengeluaran-pengeluaran negara. Untuk menjalankan tugas-tugas rutin negara dan melaksanakan pembangunan negara membutuhkan biaya. Biaya ini dapat diperoleh dari penerimaan pajak; b. Fungsi Mengatur (Regurelend), yaitu sebagai alat untuk mencapai tujuan tertentu di bidang keuangan (umpamanya bidang ekonomi, politik, budaya, pertahanan keamanan) misalnya: mengadakan perubahan tarif, memberikan pengecualian-pengecualian, keringanan-keringanan atau sebaliknya pemberatan-pemberatan yang khusus ditunjukan kepada masalah tertentu. Pemerintah bisa mengatur pertumbuhan ekonomi melalui kebijaksanaan pajak. Dengan fungsi mengatur, pajak bisa digunakan sebagai alat untuk mencapai tujuan. Pelaksanaan fungsi mengatur dapat bersifat positif dan dapat bersifat negatif. Pelaksanaan fungsi pajak yang positif maksudnya jika suatu kegiatan yang dilakukan masyarakat oleh pemerintah di pandang sebagai sesuatu yang positif, oleh karena itu didorong oleh pemerintah dengan memberikan dorongan berupa insentif pajak yang dilakukan dengan cara pemberian fasilitas perpajakan. Sementara itu, pelaksanaan fungsi mengatur yang bersifat negatif dimaksudkan untuk mencegah atau menghalangi perkembangan yang menjuruskan kehidupan masyarakat ke arah tujuan tertentu."

Pengertian Pajak Pertambahan Nilai menurut beberapa ahli antara lain sebagai berikut. Pajak pertambahan nilai (PPN) merupakan pajak yang dikenakan atas konsumsi di dalam negeri (di dalam Daerah Pabean), baik konsumsi barang maupun konsumsi jasa (Waluyo, 2013). Sedangkan menurut Mardiasmo (Mardiasmo, 2011), pajak Pertambahan Nilai adalah pajak yang dikenakan atas setiap pertambahan nilai dari barang atau jasa dalam peredarannya dari produsen ke konsumen (Mardiasmo, 2011).

Menurut Siti Kurnia Rahayu dalam Trimanda (2014): "Pajak Pertambahan Nilai adalah Pajak yang dikenakan terhadap pertambahan nilai (Value Added) yang timbul akibat dipakainya faktor-faktor produksi di setiap jalur perusahaan dalam menyiapkan, 
menghasilkan, menyalurkan dan memperdagangkan barang atau pemberian pelayanan jasa kepada para konsumen."

Berdasarkan beberapa pengertian Pajak Pertambahan Nilai dari beberapa ahli tersebut, dapat diketahui bahwa Pajak Pertambahan Nilai (PPN) adalah pajak yang dikenakan atas setiap pertambahan nilai dari barang atau jasa yang timbul akibat faktorfaktor produksi di setiap jalur perusahaan yang dikonsumsi di dalam negeri (di dalam Daerah Pabean).

Menurut Waluyo (Waluyo, 2013), "PPN memiliki beberapa karakter antara lain: a. PPN merupakan Pajak Tidak langsung, secara ekonomis beban Pajak Pertambahan Nilai dapat dialihkan kepada pihak lain. Tanggung jawab pembayaran pajak yang terutang berada pada pihak yang menyerahkan barang atau jasa, akan tetapi pihak yang menanggung beban pajak berada pada penanggung pajak (pihak yang memikul pajak); b. PPN merupakan Pajak Objektif, timbulnya kewajiban membayar pajak sangat ditentukan oleh adanya objek pajak. Kondisi subjektif subjek pajak tidak dipertimbangkan; c. Multi-Stage Tax, PPN dikenakan secara bertahap pada setiap mata rantai jalur produksi dan distribusi; d. Non-Komulatif, PPN tidak bersifat komulatif, karena PPN mengenal adanya mekanisme pengkreditan pajak masukan. Oleh karena itu, PPN yang dibayar bukan merupakan unsur harga pokok barang atau jasa; e. Single Tariff (Tarif Tunggal), PPN Indonesia hanya mengenal satu jenis tariff yaitu $10 \%$ (sepuluh persen) untuk penyerahan dalam negeri dan $0 \%$ (nol persen) untuk ekpor barang kena pajak; f. Credit Method/Invoice Method/ Indirect Substruction Method, metode ini mengandung pengertian bahwa pajak yang terutang diperoleh dari hasil pengurangan pajak yang dipungut atau pajak keluaran dengan pajak yang dibayar atau disebut pajak masukan; g. Pajak atas konsumsi dalam negeri, atas impor BKP dikenakan PPN sedangkan atas BKP tidak dikenakan PPN, prinsip ini menggunakan prinsip tempat tujuan yaitu pajak dikenakanditempat barang atau jasa akan dikonsumsi; h. Consumtion Type Value Added Tax, dalam PPN Indonesia, Pajak Masukan atas pembelian dan pemeliharaan barang modal dapat dikreditkan dengan Pajak Keluaran yang dipungut atas penyerahan BKP dan atau JKP.

Menurut Djuanda dan Lubis (2011:2), “pemungutan Pajak Pertambahan Nilai memiliki beberapa sifat, antara lain adalah sebagai berikut; 1 . Menghilangkan pajak berganda; 2. Tarif tunggal, sehingga memudahkan pelaksanaannya; 3. Menghindarkan penyelundupan pajak; 4. Netral dalam perdagangan Internasional; 5. Netral dalam persaingan dalam negeri; 6 . Netral dalam pola konsumsi; dan 7. Mendorong ekspor".

Menurut (Djuanda \& Lubis, 2011), terdapat dua prinsip pemungutan PPN, yaitu prinsip tempat tujuan (destination) dan prinsip tempat asal. Prinsip tempat tujuan artinya Pajak Pertambahan Nilai dipungut di tempat dimana barang atau jasa tersebut dikonsumsi. Sedangkan prinsip tempat asal artinya Pajak Pertambahan Nilai dipungut di tempat asal barang atau jasa yang akan dikonsumsi.

Dalam Undang-undang Nomor 42 Tahun 2009 tentang Perubahan Ketiga atas Undang-Undang Nomor 8 Tahun 1983 tentang Pajak Pertambahan Nilai Barang dan Jasa dan Pajak Penjualan Atas Barang Mewah tidak secara eksplisit disebutkan prinsip pemungutan PPN di Indonesia, namun secara implicit prinsip pemungutan Pajak 
Pertambahan Nilai di Indonesia adalah prinsip tempat tujuan. Hal ini dapat dilihat dari prinsip tempat tujuan secara substansi adalah memajaki barang ketika mereka dikonsumsi, mengembalikan pembayaran pajak atas barang ekspor dan mengenakan pajak atas impor (Doly, 2018).

Teori Fasilitas Menurut Zakiah Daradjat dalam Hasan (2016), fasilitas adalah segala sesuatu yang dapat mempermudah upaya dan memperlancar kerja dalam rangka mencapai suatu tujuan. Selanjutnya, Suharsimi Arikunto dalam Hasan (Hasan, 2016) berpendapat bahwa fasilitas dapat diartikan sebagai segala sesuatu yang dapat memudahkan dan melancarkan pelaksanaan segala sesuatu usaha. Menurut Suryo Subroto dalam Hasan (Hasan, 2016), fasilitas adalah segala sesuatu yang dapat memudahkan dan memperlancar pelaksanaan suatu usaha dapat berupa benda-benda maupun uang. Teori Pasar; Pasar adalah sekelompok pembeli dan penjual dalam suatu barang atau jasa tertentu. Pembeli sebagai kelompok yang menentukan permintaan produk, dan penjual sebagai kelompok yang menentukan persediaan produk (Mankiw, 2016).

\section{METODE PENELITIAN}

Metode penelitian yang digunakan dalam penelitian ini adalah kualitatif deskriptif. Adapun pengumpulan data yang digunakan adalah dokumentasi dan wawancara. Dokumentasi dilakukan dengan mempelajari peraturan perundangundangan serta jurnal ilmiah yang terkait dengan fasilitas PPN tidak dipungut dan PPN dibebaskan. Sedangkan wawancara dilakukan kepada narasumber yang berasal dari Direktorat Jenderal Pajak, Pusat Analisis dan Harmonisasi Kebijakan (Pushaka), dan dosen Politeknik Keuangan Negara STAN. Hal ini dimaksudkan karena ketentuan perpajakan berasal dari kebijakan yang diterbitkan dan oleh kementerian keuangan. Sedangkan Direktorat Jenderal Pajak merupakan institusi pelaksana ketentuan perpajakan tersebut. Dan Politeknik Keuangan Negara STAN merupakan tempat akademisi keuangan negara dan berbagai penelitian terkait keuangan negara termasuk juga sektor perpajakan. Tujuan penelitian ini adalah untuk menjelaskan dan mengetahui perbandingan antara fasilitas PPN tidak dipungut dan dibebaskan dari pengenaan PPN di Tempat Lain dalam Daerah Pabean serta menjelaskan permasalahan yang ditimbulkan oleh penerapan fasilitas PPN tersebut.

\section{HASIL PEMBAHASAN}

\section{Fasilitas Pajak Pertambahan Nilai Tidak Dipungut}

Menurut Tasripin selaku Penelaah Keberatan di Direktorat Keberatan dan Banding yang memberikan pendapat dari sudut pandang Direktorat Jenderal Pajak, Fasilitas Pajak Pertambahan Nilai tidak dipungut merupakan fasilitas yang sebenarnya ditujukan kepada Pengusaha Kena Pajak (PKP) sehingga para PKP bisa bersaing karena pada penyerahan yang merekalakukan tidak terdapat PPN yang harus dipungut sehingga menyebabkanharga yang lebih murah. Di sisi lain, para PKP tersebut juga tetap dapat mengkreditkan Pajak Masukan atas perolehan barang yang terkait dengan penyerahan BKP dan/atau JKP yang mendapat fasilitas PPN tidak dipungut. 
Selanjutnya, Andri Marfiana selaku Dosen Politeknik Keuangan Negara STAN berpendapat bahwa fasilitas PPN tidak dipungut adalah fasilitas yang diberikan atas objek tertentu yang sebenarnya atas transaksinya terutang Pajak Pertambahan Nilai, tetapi diberikan fasilitas atas PPN tersebut tidak dipungut. Pada fasilitas PPN inimekanisme PPN tetap berjalan, hanya saja atas Pajak Keluaran yang terutang tidak dipungut. Mekanisme ini menyebabkan Pajak Masukan atas transaks itersebut tetap dapat dikreditkan.

Menurut Andi Nugroho Suryo Kuncoro selaku anggota bidang Analisis dan Harmonisasi Pendapatan dan Pembiayaan Negara di Pusat Analisis dan Harmonisasi Kebijakan (Pushaka) bahwa fasilitas PPN tidak dipungut adalah fasilitas yang diberikan berdasarkan zona atau kawasan tertentu. Oleh sebab itu, fasilitas PPN tidak dipungut tidak diberikan hanya kepada barang atau komoditas tertentu, tetapi diberikan lebih berfokus kepada kawasan ekonomi tertentu sehingga fasilitas PPN tidak dipungut dapat diberikan kepada lebih banyak aktivitas ekonomi.

Sedangkan berdasarkan penjelasan pasal 16B UU Nomor 42 Tahun 2009, perlakuan khusus atau fasilitas berupa Pajak Pertambahan Nilai yang terutang, tetapi tidak dipungut, artinya bahwa Pajak Masukan yang berkaitan dengan penyerahan Barang Kena Pajak dan/atau Jasa Kena Pajak yang mendapat perlakuan khusus dimaksud tetap dapat dikreditkan. Dengan demikian, Pajak Pertambahan Nilai tetap terutang, tetapi tidak dipungut.

Tabel 1 Perbandingan PPN Tanpa Fasilitas dan Fasilitas PPN Tidak Dipungut

\begin{tabular}{|l|c|c|}
\hline \multicolumn{1}{|c|}{ Uraian } & $\begin{array}{c}\text { Mekanis PPN } \\
\text { Tanpa Fasilitas }\end{array}$ & $\begin{array}{c}\text { Mekanis PPN } \\
\text { Tidak Dipungut }\end{array}$ \\
\hline $\begin{array}{l}\text { Harga perolehan bahan baku, peralatan, dan } \\
\text { jasa lainnya terkait penyerahan BKP dan/atau } \\
\text { JKP }\end{array}$ & $\mathrm{Rp} 10.000 .000$ & $\mathrm{Rp} 10.000 .000$ \\
\hline Pajak Masukan & $(\mathrm{Rp} \mathrm{1.000.000)}$ & $(\mathrm{Rp} \mathrm{1.000.000)}$ \\
\hline $\begin{array}{l}\text { Nilai Perolehan setelah ditambah Pajak } \\
\text { Masukan }\end{array}$ & $\mathrm{Rp} 11.000 .000$ & $\mathrm{Rp} 11.000 .000$ \\
\hline Harga penyerahan BKP dan/atau JKP & $\mathrm{Rp} 12.000 .000$ & $\mathrm{Rp} 12.000 .000$ \\
\hline Pajak Keluaran & $\mathrm{Rp} 1.200 .000$ & TidakDipungut \\
\hline Jumlah yang harus ditanggung Pembeli & $\mathrm{Rp} 13.200 .000$ & $\mathrm{Rp} 12.000 .000$ \\
\hline PPN Kurang atau (Lebih) Bayar & $\mathrm{Rp} 200.000$ & $(\mathrm{Rp} 1.000 .000)$ \\
\hline
\end{tabular}

Sumber: Diolah Penulis

Ilustrasi yang disajikan dalam Tabel1 menunjukan bahwa dengan diberikannya fasilitas PPN tidak dipungut atas suatu transaksi, jumlah akhir yang ditanggung pembeli lebih kecil dibandingkan dengan apabila transaksi tersebut dikenakan PPN. Hal ini disebabkan karena pembeli tidak perlu menanggung PPN karena atas transaksi tersebut diberikan fasilitas PPN tidak dipungut. Selain itu, atas PPN PajakMasukan yang terkait dengan transaksi tersebut tetap dapat dikreditkan oleh PKP penjual. 
PUBLIK: Jurnal Manajemen Sumber Daya Manusia, Adminsitrasi dan Pelayanan Publik Sekolah Tinggi Ilmu Administrasi Bina Taruna Gorontalo Volume VIII Nomor 1, 2021

Tabel 2 Penyerahan yang Mendapat Fasilitas PPN Tidak Dipungut

\begin{tabular}{|c|c|c|c|}
\hline Obyek Pajak & Asal & Tujuan & Perlakuan PPN \\
\hline Penyerahan BKP & $\begin{array}{c}\text { Daerah pabean } \\
\text { lainya }\end{array}$ & Kawasan Bebas & $\begin{array}{c}\text { PPN Tidak } \\
\text { Dipungut* }\end{array}$ \\
\hline Penyerahan BKP & $\begin{array}{c}\text { Tempat Penimbunan } \\
\text { Berikat atau } \\
\text { Kawasan Ekonomi } \\
\text { Khusus }\end{array}$ & Kawasan Bebas & $\begin{array}{c}\text { PPN Tidak } \\
\text { Dipungut }\end{array}$ \\
\hline Penyerahan BKP & Kawasan Bebas & $\begin{array}{c}\text { Tempat Penimbunan } \\
\text { Berikat atau Kawasan } \\
\text { Ekonomi Khusus }\end{array}$ & $\begin{array}{c}\text { PPN Tidak } \\
\text { Dipungut** }\end{array}$ \\
\hline
\end{tabular}

Sumber: (Sari 2018)

Keterangan:

*jika pemasukan BKP ke Kawasan Bebas tidak melalui pelabuhan atau bandar udara yang ditunjuk, maka atas pemasukan BKP tersebut dipungut PPN

**terhadap BKP yang di masukan ke Tempat Penimbunan Berikat, dipungut PPN

\section{Fasilitas Dibebaskan dari Pengenaan Pajak Pertambahan Nilai}

Menurut Tasripin (2020), fasilitas dibebaskan dari pengenaan PPN sebenarnya merupakan fasilitas yang diberikan kepada konsumen, oleh karena itu pada umumnya dikaitkan dengan jenis barang atau jasa yang diberikan fasilitas. Hal ini sejalan dengan pendapat Bapak Andi Nugroho Suryo Kuncoro selaku anggota bidang Analisis dan Harmonisasi Pendapatan dan Pembiayaan Negara di Pusat Analisis dan Harmonisasi Kebijakan (Pushaka) yang berpendapat bahwa pemberian fasilitas PPN dapat dilakukan dengan dua cara yaitu pemberian fasilitas PPN berdasarkan komoditas atau barang dan berdasarkan zona atau kawasan. Fasilitas dibebaskan dari pengenaan PPN adalah fasilitas yang diberikan dengan lebih fokus diberikan kepada barang-barang atau komoditas tertentu.

Andri Marfiana (2020) berpendapat bahwa fasilitas dibebaskan dari pengenaan PPN adalah fasilitas yang diberikan atas objek tertentu, yang sebenarnya atas transaksi tersebut terutang PPN, tetapi atas transaksinya dibebaskan PPN. Fasilitas ini dalam mekanismenya Pajak Masukan atas perolehan BKP/JKP tidak dapat dikreditkan, karena Pajak Keluaran atas transaksi tersebut tidak ada. Berbeda dengan tidak dipungut, Pajak Keluaran atas PPN tidak dipungut tetap ada, tetapi tidak dipungut oleh PKP.

Sedangkan dalam penjelasan pasal 16B ayat (3) UU Nomor 42 Tahun 2009 dijelaskan bahwa berbeda dengan ketentuan fasilitas PPN tidak dipungut, adanya perlakuan khusus berupa pembebasan dari pengenaan Pajak Pertambahan Nilai mengakibatkan tidak adanya Pajak Keluaran, sehingga Pajak Masukan yang berkaitan dengan penyerahan Barang Kena Pajak dan/atau Jasa Kena Pajak yang memperoleh pembebasan PPN tersebut tidak dapat dikreditkan.

Selanjutnya Bapak Andi juga berpendapat bahwa terdapat tiga tujuan utama pemberian fasilitas dibebaskan dari pengenaan PPN antara lain: a. Meningkatkan pertumbuhan ekonomi; b. Meningkatkan daya saing untuk meningkatkan jumlah produsen. 
Pertambahan jumlah produsen dapat menghindarkan terjadinya pasar monopoli atau oligopoly; dan c. Untuk meringankan beban konsumen secara tidak langsung. Dengan meningkatkan pertumbuhan ekonomi dan meningkatnya daya saing antar produsen, harga-harga barang menjadi lebih rendah dan terjangkau. Hal ini disebabkan dari dua sisi, yaitu (1) meningkatnya jumlah produsen sehingga produsen menjadi price taker dan (2) yaitu daya beli konsumen bertambah.

Tabel 3 Perbandingan Mekanisme PPN Tanpa Fasilitas dan Dibebaskan dari Pengenaan PPN

\begin{tabular}{|l|r|r|}
\hline \multicolumn{1}{|c|}{ Uraian } & $\begin{array}{c}\text { Mekanis PPN } \\
\text { Tanpa Fasilitas } \\
(\mathrm{Rp})\end{array}$ & $\begin{array}{c}\text { Mekanis Dibebaskan } \\
\text { dari Pengenaan PPN } \\
(\mathrm{Rp})\end{array}$ \\
\hline $\begin{array}{l}\text { Harga perolehan bahan baku, peralatan, } \\
\text { dan jasa lainnya terkait penyerahan BKP } \\
\text { dan/atau JKP }\end{array}$ & 10.000 .000 & 10.000 .000 \\
\hline Pajak Masukan & 1.000 .000 & $\begin{array}{r}\text { Tidak dapat } \\
\text { dikreditkan }\end{array}$ \\
\hline $\begin{array}{l}\text { Nilai Perolehan setelah ditambah Pajak } \\
\text { Masukan }\end{array}$ & 11.000 .000 & 11.000 .000 \\
\hline Harga penyerahan BKP dan/atau JKP & 12.000 .000 & 12.000 .000 \\
\hline Pajak Keluaran & 1.200 .000 & - \\
\hline Jumlah yang ditanggung oleh Pembeli & 3.200 .000 & - \\
\hline PPN Kurang atau (Lebih) Bayar & 200.000 & 12.000 .000 \\
\hline
\end{tabular}

Sumber: Diolah Penulis

Ilustrasi yang disajikan dalam Tabel3 menunjukan bahwa dengan diberikannya fasilitas dibebaskan dari pengenaan PPN atas suatu transaksi, jumlah akhir yang ditanggung pembeli lebih kecil dibandingkan dengan apabila transaksi tersebut dikenakan PPN. Namun, atas PPN Pajak Masukan yang terkait dengan transaksi tersebut tidak dapat dikreditkan oleh PKP penjual.

\section{Perbandingan fasilitas PPN Tidak Dipungut dan Dibebaskan dari pengenaan PPN di Tempat Lain Dalam Daerah Pabean.}

Menurut Andi Nugroho Suryo Kuncoro selaku anggota bidang Analisis dan Harmonisasi Pendapatan dan Pembiayaan Negara di Pusat Analisis dan Harmonisasi Kebijakan (Pushaka), perbedaan fasilitas PPN tidak dipungut dan dibebaskan dari pengenaan PPN dapat dilihat dari tiga aspek, yaitu dari segi pengkreditan PPN Pajak Masukan, dari segi administrasi fasilitas PPN tidak dipungut dan dibebaskan dari pengenaan PPN, dan sudut pandang ekonomi.

1. Pengkreditan PPN Pajak Masukan

Terdapat perbedaan pada aturan pengkreditan Pajak Masukan atas penyerahan BKP dan/atau JKP yang mendapat fasilitas PPN tidak dipungut atau fasilitas dibebaskan dari pengenaan PPN. Pasal 16B ayat (2) UU PPN mengatur bahwa Pajak Masukan yang dibayar untuk perolehan Barang Kena Pajak dan/atau perolehan Jasa Kena Pajak yang 
atas penyerahannya tidak dipungut Pajak Pertambahan Nilai dapat dikreditkan. Selanjutnya, pasal 16B ayat (3) UU PPN mengatur bahwa Pajak Masukan yang dibayar untuk perolehan Barang Kena Pajak dan/atau perolehan Jasa Kena Pajak yang atas penyerahannya dibebaskan dari pengenaan Pajak Pertambahan Nilai tidak dapat dikreditkan.

Fasilitas PPN tidak dipungut artinya Pajak Pertambahan Nilai atas penyerahan Barang Kena Pajak dan/atau Jasa Kena Pajak tetap terutang, tetapi tidak dipungut. Oleh karena fasilitas PPN tidak dipungut menyebabkan tetap adanya PPN yang terutang, maka Pajak Masukan yang berkaitan dengan penyerahan BKP dan/atau JKP yang mendapat perlakuan khusus atau fasilitas tidak dipungut tersebut tetap dapat dikreditkan.

Berbeda dengan ketentuan pengkreditan Pajak Masukan yang berkaitan dengan penyerahan BKP dan/atau JKP yang mendapat fasilitas PPN tidak dipungut, adanya perlakuan khusus berupa pembebasan dari pengenaan Pajak Pertambahan Nilai mengakibatkan tidak adanya Pajak Keluaran. Oleh sebab itu, Pajak Masukan yang berkaitan dengan penyerahan BKP dan/atau JKP yang memperoleh fasilitas pembebasan dari pengenaan PPN tidak dapat dikreditkan.

2. Administrasi fasilitas PPN tidak dipungut dan dibebaskan dari pengenaan PPN

Penyerahan Barang Kena Pajak dan/atau Jasa Kena Pajak baik yang mendapat fasilitas PPN tidak dipungut maupun dibebaskan dari pengenaan PPN tetap wajib diterbitkan Faktur Pajak. Penerbitan Faktur Pajak tetap wajib dilakukan meskipun BKP dan/atau JKP yang diserahkan mendapat fasilitas karena sebenarnya transaksi yang mendapat fasilitas tersebut seharusnya terutang PPN dan tidak termasuk bukan Barang Kena Pajak (non BKP). Hal ini dilakukan untuk menjaga akuntabilitas dimana dalam prisip akuntansi, semua transaksi yang terjadi baik atas BKP maupun non BKP harus diungkapkan.

Pengusaha Kena Pajak yang melakukan penyerahan BKP dan/atau JKP yang mendapat fasilitas PPN tidak dipungut harus menerbitkan Faktur Pajak dengan kode faktur 07. Sedangkan Pengusaha Kena Pajak yang melakukan penyerahan BKP dan/atau JKP yang mendapat fasilitas dibebaskan dari pengenaan PPN wajib menerbitkan faktur pajak dengan kode faktur 08. "Kode faktur pajak 08 digunakan atas penyerahan yang mendapat fasilitas dibebaskan dari pengenaan PPN, berdasarkan peraturan khusus yang berlaku antara lain: a. Ketentuan yang mengatur mengenai impor dan/atau penyerahan Barang Kena Pajak tertentu dan/atau penyerahan Jasa Kena Pajak Tertentu yang dibebaskan dari pengenaan Pajak Pertambahan Nilai; b. Ketentuan yang mengatur mengenai impor dan/atau penyerahan Barang Kena Pajak tertentu yang bersifat strategis yang dibebaskan dari pengenaan Pajak Pertambahan Nilai; c. Ketentuan yang mengatur mengenai pemberian pembebasan Pajak Pertambahan Nilai dan/atau Pajak Penjualan atas Barang Mewah kepada Perwakilan Negara Asing dan Badan Internasional serta pejabatnya."

3. Sudut Pandang Ekonomi

Tujuan pemberian fasilitas Pajak Pertambahan Nilai berupa PPN tidak dipungut dan dibebaskan dari pengenaan PPN sesuai dengan penjelasan Pasal 16B UU PPN 
adalah untuk memberikan fasilitas perpajakan yang benar-benar diperlukan terutama untuk berhasilnya sektor kegiatan ekonomi yang berprioritas tinggi dalam skala nasional, mendorong perkembangan dunia usaha dan meningkatkan daya saing, mendukung pertahanan nasional, serta memperlancar pembangunan nasional. Dengan kata lain, tujuan pemberian kedua fasilitas ini adalah untuk menumbuhkan ekonomi, menumbuhkan investasi, dan menumbuhkan konsumsi Dalam Negeri atas barangbarang terkait, tidak hanya atas barang-barang yang mendapat fasilitas tetapi juga barang-barang turunannya.

Untuk mencapai tujuan tersebut, pemberian fasilitas PPN dapat dilakukan dengan dua cara yaitu pemberian fasilitas PPN berdasarkan komoditas atau barang dan berdasarkan zona atau kawasan. Fasilitas dibebaskan dari pengenaan PPN lebih fokus diberikan kepada barang-barang atau komoditas tertentu. Sedangkan fasilitas PPN tidak dipungut lebih fokus diberikan berdasarkan zona atau kawasan tertentu.

Fasilitas PPN dibebaskan lebih fokus diberikan terhadap komoditas atau barang, utamanya barang yang bersifat strategis dengan tujuan: (1) dari sisi konsumsi (permintaan), yaitu agar mobilitas barang yang memiliki urgensi yang tinggi bagi masyarakat lebih mudah tersalurkan; dan (2) dari sisi penawaran, yaitu agar pelaku usaha yang bergerak di sektor penyediaan barang strategis sebagaimana dimaksud dalam Peraturan Pemerintah Nomor 81 Tahun 2015 dapat meningkatkan produksi dan menawarkan produknya lebih banyak.

Salah satu Barang Kena Pajak yang mendapat fasilitas dibebaskan dari pengenaan PPN adalah pakan ternak tidak termasuk pakan hewan kesayangan. Dengan diberikan fasilitas PPN dibebaskan, diharapkan geliat ekonomi dari jalur distribusi meningkat, mulai dari peternak hingga kepabrik pemotongan maupun pengemasan daging, termasuk hingga pedagang perantara ke pasar tradisional.

Sedangkan pemberian fasilitas PPN tidak dipungut tidak lebih spesifik dari pada fasilitas dibebaskan dari pengenaan PPN karena diberikan untuk hampir semua aktivitas penyerahan yang berada di kawasan ekonomi tertentu seperti di Kawasan Perdagangan Bebas dan Kawasan Berikat serta tidak hanya terfokus kepada barang-barang tertentu seperti fasilitas dibebaskan dari pengenaan PPN.Tujuan pemberian fasilitas PPN tidak dipungut sama dengan fasilitias PPN dibebaskan, perbedaannya terletak pada fokus pemberian fasilitas.

Pasal 16B Undang-undang PPN mengatur bahwa terdapat dua fasilitas PPN yang diberikan negara yaitu PPN tidak dipungut dan dibebaskan dari pengenaan PPN, baik untuk sementara waktu maupun selamanya. Perbedaan yang mendasar dari kedua fasilitas tersebut terletak pada pengkreditan Pajak Masukan yang terkait dengan penyerahan yang mendapat fasilitas PPN.

Pengusaha yang melakukan penyerahan yang mendapat fasilitas dibebaskan dari pengenaan PPN tidak dapat mengkreditkan Pajak Masukan yang terkait dengan transaksi tersebut. Oleh karena itu, pengusahaakan membebankan Pajak Masukan tersebut dalam laporan rugi laba. Pembebanan Pajak Masukan ini memungkinkan terjadinya masalah berupa harga yang ditanggung pembeli menjadi lebih tinggi. Dengan asumsi margin keuntungan yang diperoleh perusahaan tidak berubah, harga jual barang 
akan meningkat karena harga pokok penjualan meningkat. Masyarakat luas akan merasa kesulitan untuk menanggung harga jual barang tersebut (Ginting \& Wijaya, 2018). Dengan adanya pembebanan Pajak Masukan tersebut, pengusaha mungkin akan menaikan harga jual produknya untuk dapat memperoleh margin laba yang sama dengan apabila produk yang dijual tidak mendapat fasilitas dibebaskan dari pengenaan PPN.

Menurut Andi N.S Kuncoro, PPN Pajak Masukan yang tidak dapat dikreditkan dan dibiayakan oleh pengusaha memiliki kemungkinan mempengaruhi harga barang menjadi lebih tinggi atau tidak tergantung pada jenis pasar atas barang tersebut.

PPN Pajak Masukan yang tidak dapat dikreditkan dan dibebankan sebagai biaya oleh Pengusaha Kena Pajak (PKP) dapat mempengaruhi harga barang menjadi lebih tinggi apabila produk yang mendapat fasilitas dibebaskan dari pengenaan PPN tersebut berada pada pasar yang bersifat monopolistik (monopoli atau oligopoli). Hal ini dimungkinkan karena dalam pasar yang bersifat monopolistik, pengusaha berperan sebagai penentu harga (price maker) karena tidak memiliki pesaing sehingga perusahaan memiliki kekuatan untuk mempengaruhi harga pasar dari produknya.

Sebaliknya, PPN Pajak Masukan yang tidak dapat dikreditkan dan dibebankan sebagai biaya oleh Pengusaha Kena Pajak (PKP) tidak akan mempengaruhi harga barang menjadi lebih tinggi apabila jenis pasar barang tersebut adalah pasar persaingan sempurna. Hal ini disebabkan karena dalam pasar persaingan sempurna, produsen akan menjadi pengguna harga (price taker) dan tidak hanya sebagai penentu harga (price maker). Sehingga, produsen tidak akan dapat semata-mata menentukan tingkat margin laba yang diinginkan, karena apabila satu produsen menentukan harga terlalu tinggi, produsen tersebut tidak akan dapat bersaing karena produsen yang lain menawarkan produk serupa dengan harga yang lebih rendah.

Negara dengan sengaja tidak memungut suatu pajak dengan tujuan agar perekonomian tidak terdistorsi dan diharapkan pertumbuhan ekonomi lebih tinggi karena sifat natural dari pajak adalah sebagai distorsi dari ekonomi yang menghambat pertumbuhan ekonomi. Meskipun terdapat beberapa kajian yang menyatakan bahwa pajak bukanlah distorsi dari pertumbuhan ekonomi, dimana distorsi ekonomi disebabkan oleh faktor ekonomi, yaitu ketersediaan investasi, ketersediaan capital, ketersediaan tenaga kerja yang produktif, ketersediaan teknologi, ketersediaan bahan baku, dan sebagainya. Tetapi dari perspektif perekonomian, pajak dianggap beban sehingga merupakan salah satu faktor yang menentukan keputusan pelaku ekonomi.

Fasilitas Pajak Pertambahan Nilai diharapkan dapat membuat para pelaku ekonomi lebih bergairah untuk melakukan ekspansi usaha dan pertumbuhan ekonomi lebih meningkat sehingga menarik produsen-produsen baru. Dengan bertambahnya jumlah produsen baru, menyebabkan pasar semakin sempurna sehingga produsen menjadi price taker bukan hanya sebagai price maker.

\section{KESIMPULAN}

Fasilitas PPN tidak dipungut adalah fasilitas yang diberikan atas objek tertentu yang sebenarnya atas transaksinya terutang Pajak Pertambahan Nilai, tetapi diberikan fasilitas atas PPN tersebut tidak dipungut. Fasilitas PPN tidak dipungut diberikan 
berdasarkan zona atau kawasan tertentu. Oleh sebab itu, fasilitas PPN tidak dipungut tidak diberikan hanya kepada barang atau komoditas tertentu, tetapi diberikan lebih berfokus kepada kawasan ekonomi tertentu sehingga fasilitas PPN tidak dipungut dapat diberikan kepada lebih banyak aktivitas ekonomi. Pada fasilitas PPN ini mekanisme PPN tetap berjalan, hanya saja atas Pajak Keluaran yang terutang tidak dipungut. Mekanisme ini menyebabkan Pajak Masukan atas transaksi tersebut tetap dapat dikreditkan.

Fasilitas dibebaskan dari pengenaan PPN sebenarnya merupakan fasilitas yang diberikan kepada konsumen, oleh karena itu pada umumnya dikaitkan dengan jenis barang atau jasa yang diberikan fasilitas. Fasilitas dibebaskan dari pengenaan PPN adalah fasilitas yang diberikan dengan lebih fokus diberikan kepada barang-barang atau komoditas tertentu. Berbeda dengan ketentuan fasilitas PPN tidak dipungut, adanya perlakuan khusus berupa pembebasan dari pengenaan Pajak Pertambahan Nilai mengakibatkan tidak adanya Pajak Keluaran, sehingga Pajak Masukan yang berkaitan dengan penyerahan Barang Kena Pajak dan/atau Jasa Kena Pajak yang memperoleh pembebasan PPN tersebut tidak dapat dikreditkan.

Perbedaan fasilitas PPN tidak dipungut dan dibebaskan dari pengenaan PPN dapat dilihat dari tiga aspek, yaitu dari segi pengkreditan PPN Pajak Masukan, dari segi administrasi fasilitas PPN tidak dipungut dan dibebaskan dari pengenaan PPN, dan sudut pandang ekonomi. Dari segi pengkreditan PPN Pajak Masukan, terdapat perbedaan yang mendasar dari fasilitas PPN tidak dipungut dan dibebaskan dari pengenaan PPN. PPN PM yang berkaitan dengan penyerahan BKP dan/atau JKP yang mendapat fasilitas PPN tidak dipungut tetap dapat dikreditkan sedangkan PPN PM yang berkaitan dengan penyerahan BKP dan/atau JKP yang memperoleh pembebasan PPN tersebut tidak dapat dikreditkan. Dari segi administrasi, penyerahan yang mendapat fasilitas PPN tidak dipungut diterbitkan Faktur Pajak dengan kode 07 sedangkan penyerahan yang mendapat fasilitas dibebaskan dari pengenaan PPN diterbitkan Faktur Pajak dengan kode 08. Dari sudut pandang ekonomi, fasilitas PPN dibebaskan lebih fokus diberikan terhadap komoditas atau barang, utamanya barang yang bersifat strategis sedangkan fasilitas PPN tidak dipungut lebih fokus diberikan berdasarkan zona atau kawasan tertentu.

PPN Pajak Masukan yang tidak dapat dikreditkan dan dibiayakan oleh pengusaha memiliki kemungkinan mempengaruhi harga barang menjadi lebih tinggi atau tidak tergantung pada jenis pasar atas barang tersebut. PPN Pajak Masukan yang tidak dapat dikreditkan dan dibebankan sebagai biaya oleh Pengusaha Kena Pajak (PKP) dapat mempengaruhi harga barang menjadi lebih tinggi apabila produk yang mendapat fasilitas dibebaskan dari pengenaan PPN tersebut berada pada pasar yang bersifat monopolistik (monopoli atau oligopoli). Sebaliknya, PPN Pajak Masukan yang tidak dapat dikreditkan dan dibebankan sebagai biaya oleh Pengusaha Kena Pajak (PKP) tidak akan mempengaruhi harga barang menjadi lebih tinggi apabila jenis pasar barang tersebut adalah pasar persaingan sempurna.

Tujuan pemberian fasilitas untuk menumbuhkan ekonomi harus dibarengi dengan cut the government. Pemberian fasilitas PPN harus dibarengi dengan simplifikasi 
birokrasi. Salah satu cara yang dapat dilakukan adalah dengan menciptakan pelaporan satu pintu sehingga dapat mengurangi biaya administrasi yang dikeluarkan oleh pihak yang memanfaatkan fasilitas PPN.

Akuntabilitas fasilitas PPN harus ditingkatkan, karena selama ini hanya dilaporkan dengan revenue forgone method. Revenue forgone method yang dianut dalam pembuatan Tax Expenditure Report mengandung banyak kelemahan karena metode tersebut merupakan metode yang statis, dimana tidak memperhitungkan perilaku konsumen dan jenis pasar dari suatu komoditas (monopolistic, monopoli, atau oligopoly), padahal setiap komoditas memiliki jenis pasar yang berbeda.

\section{DAFTAR PUSTAKA}

Afriyanti, V. (2014). Tata cara pemungutan PPN kegiatan membangun sendiri (KMS) di KPP Pratama Pekanbaru Senapelan.

Badan Kebijakan Fiskal. (2019). Laporan belanja perpajakan 2018. Jakarta.

Djuanda, G., \& Lubis, I. (2011). Pelaporan pajak pertambahan nilai dan pajak penjualan atas barang mewah edisi revisi. Jakarta: Gramedia.

Doly, T. (2018). Mekanisme prinsip pemungutan PPN.

Ginting, M. E., \& Wijaya, S. (2018). Pajak pertambahan nilai terhadap penyerahan air bersih: Dibebaskan atau tidak dipungut?

Hasan, A. H. (2016). Pengaruh kualitas fasilitas perpustakaan dan kualitas media pembelajaran terhadap prestasi belajar fiqh siswa MTS Daru'L Hikam Kota Cirebon.

Hestanto, A. (2018). Konsep dasar perpajakan menurut para cendekiawan.

Mankiw, N. (2016). Principles of economics (8th ed.). Boston: Cengage Learning.

Mardiasmo. (2011). Perpajakan edisi revisi. Jakarta: Salemba Empat.

Pietersz, J. J., Picauly, B. C., Widaryanti, W., Katili, A. Y., Ririhena, M. Y., Ferayani, M. D., ... Suripto, S. (2021). PERPAJAKAN (TEORI \& PRAKTIK). Widina Bhakti Persada Bandung. Bandung: Widina Bhakti Persada Bandung.

Sulistyawati, L. (2019, January). IKAPI desak pemerintah hapus pajak buku. Republika.

Sumarsan, T. (2017). Perpajakan Indonesia: Pedoman perpajakan yang lengkap berdasarkan undang-undang terbaru. Jakarta: Indeks.

Suwiknyo, E. (2019, July). Rasio pajak Indonesia ternyata di bawah rata-rata OECD. Bisnis.

Trimanda, C. (2014). Pengaruh SPT dan SSP terhadap penerimaan pajak pertambahan nilai (studi kasus Kantor Pelayanan Pajak Pratama Palembang Seberang Ulu).

Waluyo. (2013). Perpajakan Indonesia. Jakarta: Salemba Empat. 